\title{
Caspase Recruitment Domain-Containing Protein 14
}

National Cancer Institute

\section{Source}

National Cancer Institute. Caspase Recruitment Domain-Containing Protein 14. NCI

Thesaurus. Code C118912.

Caspase recruitment domain-containing protein 14 (1004 aa, $113 \mathrm{kDa})$ is encoded by the human CARD14 gene. This protein plays a role in the promotion of cell survival. 